\title{
Interactive comment on "Structural and functional control of surface-patch to hillslope-scale runoff and sediment connectivity in Mediterranean-dry reclaimed slope systems" by Mariano Moreno-de-las-Heras et al.
}

Mariano Moreno-de-las-Heras et al.

mariano.moreno@idaea.csic.es

Received and published: 3 April 2020

The comment was uploaded in the form of a supplement:

https://www.hydrol-earth-syst-sci-discuss.net/hess-2019-572/hess-2019-572-AC2-

supplement.pdf 